Review

\title{
China Launches Its First Passenger Aircraft
}

\author{
Relly Victoria Virgil Petrescu \\ ARoTMM-IFToMM, Bucharest Polytechnic University, Bucharest, (CE) Romania
}

Article history

Received: 27-02-2019

Revised: 16-03-2019

Accepted: 11-04-2019

Email: rvvpetrescu@gmail.com
Abstract: C919, the passenger plane developed by China within a national project, was successfully launched at the inauguration of its flight. After a series of long delays, this is only the first step by which China is trying to penetrate the international aviation market. C919, developed and produced by Aircraft Corp. or COMAC in brief, was initially scheduled to be prepared in 2012 with its first flight in 2016. Despite these delays, COMAC will be a serious competitor in the future for the leaders of the Boeing and Airbus civil aviation market, given that C919 will be up to $50 \%$ lower than the models produced by American and European competitors. This first model of the airplane, still under test, was taken off from Shanghai Pudong Airport, the event being broadcast live by the media in the Chinese state. The latter declared the success of this project as a reason for national pride, only six other countries in the world have managed to produce a line plane of this size, especially in the context in which just days ago China launched the first the aircraft produced entirely on the domestic market. China's ambition to develop its own civil aviation industry dates back to the 1970s when Mao Zedong's wife, Jiang Qing, supported the personal development of this sector. "A strong country must have its own passenger plane. China's commercial aviation industry cannot depend entirely on imports," said Li Jiaxiang, the head of China's civil aviation authority. Between 150 and 170 passenger seats, C919 will be a competitor for Boeing 737 and Airbus 320. Incorporating a state-of-the-art engine, specialists in the field believe the C919 is comparable as their competitors. The plane is not fully developed in China, the engine, electronics, wheels, brakes and many other components being manufactured mainly in Europe and the United States. Airplane price is announced to be about 500 million dollars, with about 100 million dollars below the price of the catalog of its competitors. Price differences may, however, increase in the case of large orders. Chinese media announced that there are already orders for 570 C919 devices from Chinese aviation companies. It is estimated that the global civil aviation market will total $\$ 2$ trillion in the next 20 years. Boeing estimates that just to cope with the domestic market, Chinese airlines will have to acquire over 6,000 passenger planes of different sizes, the cost of which is close to 1 trillion dollars. The next step for the C919 to enter the global market will be the required certificates from American and European agencies, the FAA and EASA, which regulate the commercial aviation sector. Qatar Airways CEO Akbar Al Baker said shortly afterward that "there is no hesitation in a plane made in China, as long as they are built to a certain standard. There is nothing wrong with buying China-made products, but we are using China-made iPhone designed by someone else but manufactured in China. I think it will be good if this monopoly (Boeing/Airbus) is broken" he added this.

Keywords: China, China Aircraft Corp, China First Passenger Aircraft

\section{Introduction}

The People's Republic of China is an independent state located in East Asia. It is the most populous country in the world, with a population of over 1,350,000,000. China has a unit system, led by the Chinese Communist Party, having its headquarters in the capital city of Beijing. It exercises jurisdiction over 22 provinces, five autonomous 
regions, four central sub-municipalities (Beijing, Tianjin, Shanghai and Chongqing) and two special administrative regions, largely self-governing (Hong Kong and Macao). The PRC also claims Taiwan, as the province's twentythird, which is currently controlled by a separate political entity, the Republic of China (RC); a controversial claim due to Taiwan's complex political status.

Covering approximately 9.6 million $\mathrm{km}^{2}$, China is the size of the land area of the second country in the world and the third/fourth country by total area, according to the measurement method. China's landscape is vast and diverse, ranging from steppes and deserts, such as Gobi and Taklamakan, from the northern arid to the subtropical wetlands of the south. Mountain chains such as the Himalayas, Karakoram, Pamir and the Tian Shan separate China from the South and the Center of Asia. The Yangtze and Galben, as the third and seventh lengths of the world, flow from the Tibetan plateau to the densely populated east coast. China's coast, along with the Pacific Ocean, is $14,500 \mathrm{~km}$ long and is bordered by the seas of Bohai, Yellow, East China and South China.

China's history begins from the ancient civilization era - one of the oldest in the world - that has flourished in the fertile basin of the Yellow River in the North China Plain. For millennia, China's political system has been based on the hereditary monarchs, known as the Dynasties, starting with Semi-Semitic Xia, in the Yellow River Basin (about 2000 BC). Since the year 221 BC, when the Qin Dynasty conquered a number of states, to form a Chinese empire, the country has expanded, divided and reunified several times. The Republic of China (1912-1949) (RC) overthrew the last dynasty in 1911 and drove mainland China until 1949. After the defeat of the Japanese Empire in the Second World War, the Communist Party defeated the Kuomintang nationalists in mainland China and proclaimed the People's Republic of China in Beijing on October 1, 1949, while the Kuomintang moved the RC government to the current capital, Taipei.

Since the introduction of economic reforms in 1978, China has become one of the world's largest economies with the fastest growing economic growth. In 2013, it was the second largest economy in the world, with both total nominal GDP and purchasing power parity (PPP) and is also the world's largest exporter and importer of goods. China is one of the nuclear-weapon countries and has the largest permanent army, with the world's secondlargest budget ever-defense-minded. The PRC is a member of the United Nations since 1971 when it replaced $\mathrm{RC}$ as a permanent member of the UN Security Council. China is also a member of numerous formal and informal multilateral organizations, including the WTO, APEC, BRICS, the Shanghai Cooperation Organization, the BCIM and the G-20. China is a regional power in Asia and has been characterized as a potential superpower by a number of analysts.
The People's Republic of China is the second largest country in the world, by dry area, following Russia and is third, or fourth, the largest total area after Russia, Canada and, depending on the way of calculation, the United States of America. In general, China's total area is estimated to be about $9,600,000 \mathrm{~km}^{2}$. The figures range from $9,572,900 \mathrm{~km}^{2}$, according to the Britannica Encyclopedia, 9,596,961 $\mathrm{km}^{2}$, according to the UN Demographic Yearbook, at 9,596,961 $\mathrm{km}^{2}$, according to the CIA World Factbook. China has the longest land border in the world, $22,117 \mathrm{~km}$, from the sinking of the Yalu River to the Tonkin Bay. China is bordered by 14 nations, more than any other country, except for Russia, which is also bordering 14 states. China extends largely from East Asia, bordering Vietnam, Laos, Burma in Southeast Asia; with India, Bhutan, Nepal and Pakistan in South Asia [e]; with Afghanistan, Tajikistan, Kyrgyzstan and Kazakhstan in Central Asia; with Russia, Mongolia, North Korea in North and Northeast Asia. In addition, China divides maritime borders with South Korea, Japan, Vietnam, the Philippines and Taiwan.

China's territory lies between latitudes $18^{\circ}$ and $54^{\circ} \mathrm{N}$ and between $73^{\circ}$ and $135^{\circ} \mathrm{E}$ longitude. China's landscapes vary widely across the vast territory. In the east, along the shores of the Yellow Sea and the East China Sea are extensive and densely populated alluvial plains, while on the edges of the Inner Mongolia Plate, in the north, large meadows prevail. South China is dominated by hills and low mountain ranges, while the central-eastern part hosts the delta of two major rivers of China, Yellow and the Yangtze. Other major waters include Xi, Mekong, Brahmaputra and Amur. To the west are important mountain ranges, especially the Himalayas. High plateaus show arid landscapes in the north, such as the Taklamakan and Gobi deserts. The highest point in the world, Mount Everest $(8848 \mathrm{~m})$, is on the Sino-Nepalese border. The lowest point of the country and the third in the world is the bottom of Ayden's (playa) lake (-154 m) in the Turpan Depression.

China's climate is predominantly dominated by dry seasons and wet monsoons, which lead to significant temperature differences between winter and summer. In the winter, the Nordic winds, coming from higher latitudes, are cold and dry; In summer, the southern winds in the coastal latitudes of the lower latitudes are warm and humid. China's climate differs from one region to another because of its vast territory and complex topography. A major environmental problem in China is the continued expansion of its deserts, especially the Gobi Desert. Although the trees-barrier lines planted in 1970 have reduced the frequency of sand storms, prolonged drought and erroneous agricultural practices have caused dust storms that affect northern China every spring, parts of East Asia, including Korea and Japan. According to the China Environmental Protection Ministry, SEPA, China loses $4,000 \mathrm{~km}^{2}$ per year due to desertification. Water 
quality, erosion and pollution control have become important issues in China's relations with other countries. Melting glaciers in the Himalayas could lead to water shortages for hundreds of millions of people.

China is one of the 17 megadiverse countries, is located in two of the major ecological areas of the world: Palearctic and Indomalaya. According to an estimate, China has over 34,687 species of animals and vascular plants, making it the third most biodiverse in the world after Brazil and Colombia. The country signed the Rio de Janeiro Convention on Biological Diversity on 11 June 1992 and became a party to the Convention on 5 January 1993 and later a National Biodiversity Strategy and Action Plan with a review, which was accepted by the Convention on 21 September 2010.

China is the home of at least 551 mammalian species (ranked No. 3 in the world); 1221 species of birds (eighth on Terra); 424 reptile species (7th place) and 333 amphibian species (7th place on the globe). China is the country outside the tropics with the highest biodiversity. China's wildlife divides its habitat and carries the acute pressure of the world's largest homo sapiens population. At least 840 species of animals are threatened, vulnerable or in danger of extinction at a local level in China, mainly due to anthropogenic activities such as habitat destruction, pollution and food hunting, fur and traditional Chinese medicine ingredients. Endangered wildlife is protected by law and since 2005 the country has more than 2,349 natural reserves covering a total area of 149.95 million hectares, $15 \%$ of China's total land area.

China has over 32,000 species of vascular plants and is home to a variety of forest types. The cold coniferous forests predominate in the northern part of the country, supporting animal species, such as the elk, the Tibetan bear, along with over 120 bird species. Lesser tall wet coniferous forests can contain bamboo bark. Higher mountainous altitudes meet juniper and yew, bamboo is replaced by rhododendron. Subtropical forests, which predominate in central and southern China, support more than 146,000 species of flora. Tropical and seasonal wet forests, although limited to Yunnan and Hainan Island, contain a quarter of all animal and plant species found in China. China has over 10,000 species of mushrooms and of these, nearly 6,000 , which belong to the Dikarya region.

In recent decades, China has suffered from pollution and serious environmental damage. While regulations such as the Environmental Protection Act of 1979 are quite strict, they are poorly applied as they are often ignored by local communities and government officials in favor of rapid economic development. Urban air pollution is a serious health problem in the country, with the World Bank estimating in 2013 that 16 of the 20 most polluted cities in the world are located in China.
China is the world's largest emitter of carbon dioxide. The country also has drinking water problems. Approximately 298 million Chinese people in rural areas do not have access to good drinking water; by the end of $2011,40 \%$ of China's rivers were polluted by industrial and agricultural waste.

This crisis is exacerbated by the increasing lack of water, especially in the northeast of the country.

However, China is the world's largest investor in the marketing of renewable energy, with $\$ 52$ billion invested only in 2011, is a major producer of renewable energy technologies and is investing heavily in renewable energy projects on a local scale. Until 2009, more than $17 \%$ of China's energy came from renewable energy sources most notably hydroelectric power plants - from which China has a total installed capacity of 197 GW. In 2011, the Chinese government announced four billion yuan (\$ 618.55 billion) investment plans for water infrastructure and desalination projects for ten years and completing the construction of a flood prevention and anti-drought, by 2020. In 2013 China has implemented a five-year plan, worth $\$ 277$ billion, to reduce air pollution, especially in the northern part of the country.

The "Sixth National Census of the People's Republic of China" in 2010, registered a total population of approximately $1,370,536,875$.

The birth rate is $12.3 \%$ o, comparable to all European countries is one of the lowest in the world and the mortality rate is $7.1 \%$. The fertility rate is 1.55 children/woman, one of the lowest values, also from around the world.

Because of the one-child policy, China now has the highest aging population in the world. Although the law of the second child could be introduced as of 1 January 2016, a survey showed that only about one million Chinese couples want a second child.

For the coming years, population decline is projected and by 2100 the population will fall by over 400 million. The more China's economy grows, the more the birth rate will decrease. The vast majority of Chinese couples want one child.

Approximately $16.60 \%$ of the population was under $14,70.14 \%$ were aged between 15 and 59 and $13.26 \%$ over 60 years. The population growth rate for 2013 is estimated at $0.46 \%$.

Although China is a middle-income country, according to Western standards, China's rapid economic growth has lifted hundreds of millions of people out of poverty since 1978 . Today, about $10 \%$ of the Chinese population lives below the poverty line, surviving less a US dollar a day, down from $64 \%$ in 1978. Urban unemployment in China dropped to $4 \%$ by the end of 2007. Currently, the unemployment rate in the urban area is about $4.1 \%$.

With a population of more than 1.3 billion people and a decrease in natural resources, the Chinese government 
is very concerned about the population growth rate and has been working with mixed results since 1979 to implement a strict family planning policy, known as the "Single Child Policy". Prior to 2013, this policy limited families to having only one child, except ethnic minorities and a degree of flexibility in rural areas. An important relaxation of the policy was adopted in December 2013, allowing families to have two children if one parent is an only child. China's Family Planning Minister indicated in 2008 that single-child policy would remain at least until 2020. There is some resistance to this single-child policy, especially in rural areas, primarily because of the need for labor in agriculture, but also the traditional preference for boy-boys. Families violating politics often lie at censuses. Data from the 2010 census suggests that the fertility rate can now be around 1.4.

China officially recognizes 56 distinct ethnic groups, most of which are the Han Chinese, which accounts for about $91.51 \%$ of the total population. The Han Chinese the largest ethnic group in the world - are more numerous than the other ethnic groups in each provincial division except Tibet and Xinjiang. Ethnic minorities account for about $8.49 \%$ of the Chinese population, according to the 2010 census. In comparison to the 2000 census, the Han population grew by $66,537,177$ people, or by $5.74 \%$, while the combined population of the other 55 by national minorities, increased by 7,362,627 people, or $6.92 \%$. The 2010 census recorded a total of 593,832 foreign citizens living in China. The largest such groups were from South Korea $(120,750)$, the United States (71493) and Japan $(66,159)$.

Since 1986, compulsory education in China encompasses primary education and gymnasium education which together last for nine years. In 2010, about 82.5 percent of students continued their studies at a three-year high school cycle. Gaokao, China's "National Exam Admission Examination", is a prerequisite for entering most of the higher education institutions. In 2010 , 27 percent of high school graduates enrolled in higher education. Professional (vocational) education is available to students from secondary and tertiary levels.

In February 2006, the government pledged to provide full nine years of free education, including the provision of manuals and allowances. Annual investment in education has increased from less than $\$ 50$ billion in 2003 to more than $\$ 250$ billion in 2011 . However, inequality remains in spending on education. In 2010, spending per year for high school student in Beijing amounted to 20,023 CNY, while in Guizhou, one of the poorest provinces in China, spending did not go up to 3,204 CNY.

Free compulsory education in China is made up of primary and secondary school for children aged 6 to 15 years. In 2011, around $81.4 \%$ of Chinese graduated from the gymnasium. Until 2007 , there were 396,567 primary schools, 94,116 gymnasium schools and 2,236 higher education institutions.
In $2010,94 \%$ of the population over 15 years old was literate, compared with only $20 \%$ in 1950 . In 2009 , Chinese students in Shanghai obtained the best results in the world in mathematics, science and literature in the International Program for Student Assessment (PISA), a global assessment of school performance of students aged 15 years.

China is a miraculous country that has been developed lately at a galloping pace. China has succeeded in developing and strengthening the electronics and home electronics industries over the past thirty years, then in the past 15 years the car and automotive industry and has now been planning to develop its aerospace and aero industries together with its own passenger planes, so that it no longer needs to appeal to the big companies and especially to the two most famous monopoly today, namely Boeing and Airbus.

Chinese civilization originated from various regional centers along the Yellow River and the Yangtze River valleys of the Neolithic Age, but the Yellow River is considered the cradle of Chinese civilization. With thousands of years of continuous history, China is one of the oldest civilizations in the world. China's written history is found in the Shang dynasty (about 1700-1046 $\mathrm{BC})$, although historical texts, such as the records of the great historian (about $100 \mathrm{BC}$ ) and the Annals of Bamboo, state the existence of a Xia dynasty before Shang. Chinese writings were given at the end of the Shang dynasty around 1200 BC. Most Chinese culture, literature and philosophy continued to develop during the Zhou Dynasty (1045-256 BC), (Petrescu, 2012b).

The Zhou dynasty began to move to internal and external pressures in the 8th century $\mathrm{BC}$ and the kingdom was divided into the smallest states, beginning in the spring and autumn, fully manifested during the wars. This is one of the multiple periods of failed statehood in China's history (the most recent civil war in China).

Between the times of many kingdoms and warriors, the Chinese dynasties (or, more recently, the republics) ruled the whole of China (minus Xinjiang and Tibet) (and, in a certain era, including Xinjiang and/or Tibet). This practice began with the Qin dynasty: In 221 BC, Qin Shi Huang joined the various kingdoms of the warriors and created the first Chinese empire. Successive dynasties in China's history have developed bureaucratic systems that allowed the emperor in China to directly control vast territories.

The traditional position of China's history is that of alternating periods of political unity and division, China being occasionally dominated by Asian inner peoples, most of them being assimilated to the Han Chinese population. The cultural and political influences of many parts of Asia, driven by successive waves of immigration, expansion and cultural disturbances, are part of China's modern culture. 
During the Great Monday, the Communists reorganized themselves under a new leader, Mao Zedong (Mao Tse-tung). The bitter struggle between the KMT and the CCP continued openly or clandestinely through the Japanese occupation of 14 years (1931-1945) from different parts of the country. The two Chinese parties officially formed a united frontier to oppose the Japanese in 1937, during the Sino-Japanese War (1937-1945), which became part of the Second World War. After the defeat of Japan in 1945, the war between the KMT and the CCP was resumed after the reconciliation attempts and a negotiated settlement. Until 1949, the CCP established control over most of the country (see Chinese Civil War), (Huang et al., 2016; Ali et al., 2016; Kamble and Kumar, 2016; Saikia and Karak, 2016; Zeferino et al., 2016; Pravettoni et al., 2016; Bedon and Amadio, 2016; Chen and $\mathrm{Xu}, 2016$; Mavukkandy et al., 2016; Yeargin et al., 2016; Madani and Dababneh, 2016; Alhasanat et al., 2016; Elliott et al., 2016; Suarez et al., 2016; Kuli et al., 2016; Waters et al., 2016; Montgomery et al., 2016; Lamarre et al., 2016; Petrescu, 2012b; Aversa et al., 2017a; 2017b; 2017c; 2017d; 2017e; 2016a; 2016b; 2016c; 2016d; 2016e; 2016f; 2016g; 2016h; 2016i; 2016j; 2016k; 2016l; 2016m; 2016n; 2016o; Petrescu and Petrescu, 2013a; 2013b; 2013c; 2012; 2011; Petrescu, 2018; 2015a; 2015b; 2012; Petrescu et al., 2016a; 2016b; 2016c; 2017a; 2017b; 2017c; 2017d; 2017e; 2017f; 2017g; 2017h; 2017i; 2017j; 2017k; 2017l; 2018a; 2018b; 2018c; 2018d; Petrescu and Calautit, 2016a; 2016b; Daud et al., 2008; Taher et al., 2008; Zulkifli et al., 2008; Pourmahmoud, 2008; Pannirselvam et al., 2008; $\mathrm{Ng}$ et al., 2008; El-Tous, 2008; Akhesmeh et al., 2008; Nachiengtai et al., 2008; Moezi et al., 2008; Boucetta, 2008; Darabi et al., 2008; Semin and Bakar, 2008; Al-Abbas, 2009; Abdullah et al., 2009; Abu-Ein, 2009; Opafunso et al., 2009; Semin et al., 2009a; 2009b; 2009c; Zulkifli et al., 2009; Ab-Rahman et al., 2009; Abdullah and Halim, 2009; Zotos and Costopoulos, 2009; Feraga et al., 2009; Bakar et al., 2009; Cardu et al., 2009; Bolonkin, 2009a; 2009b; Nandhakumar et al., 2009; Odeh et al., 2009; Lubis et al., 2009; Fathallah and Bakar, 2009; Marghany and Hashim, 2009; Kwon et al., 2010; Aly and Abuelnasr, 2010; Farahani et al., 2010; Ahmed et al., 2010; Kunanoppadon, 2010; Helmy and El-Taweel, 2010; Qutbodin, 2010; Pattanasethanon, 2010; Fen et al., 2011; Thongwan et al., 2011; Theansuwan and Triratanasirichai, 2011; Al Smadi, 2011; Tourab et al., 2011; Raptis et al., 2011; Momani et al., 2011; Ismail et al., 2011; Anizan et al., 2011; Tsolakis and Raptis, 2011; Abdullah et al., 2011; Kechiche et al., 2011; Ho et al., 2011; Rajbhandari et al., 2011; Aleksic and Lovric, 2011; Kaewnai and Wongwises, 2011; Idarwazeh, 2011; Ebrahim et al., 2012; Abdelkrim et al., 2012; Mohan et al., 2012; Abam et al., 2012; Hassan et al.,
2012; Jalil and Sampe, 2013; Jaoude and El-Tawil, 2013; Ali and Shumaker, 2013; Zhao, 2013; El-Labban et al., 2013; Djalel et al., 2013; Nahas and Kozaitis, 2014).

\section{Materials and Methods}

C919, the passenger plane developed by China within a national project, was successfully launched at the inauguration of its flight. After a series of long delays, this is only the first step by which China is trying to penetrate the international aviation market.

C919, developed and produced by Aircraft Corp. or COMAC in brief, was initially scheduled to be prepared in 2012 with its first flight in 2016. Despite these delays, COMAC will be a serious competitor in the future for the leaders of the Boeing and Airbus civil aviation market, given that C919 will be up to $50 \%$ lower than the models produced by American and European competitors. This first model of the airplane, still under test, was taken off from Shanghai Pudong Airport, the event being broadcast live by the media in the Chinese state.

The latter declared the success of this project as a reason for national pride, only six other countries in the world have managed to produce a line plane of this size, especially in the context in which just days ago China launched the first the aircraft produced entirely on the domestic market.

China's ambition to develop its own civil aviation industry dates back to the 1970s when Mao Zedong's wife, Jiang Qing, supported the personal development of this sector. "A strong country must have its own passenger plane. China's commercial aviation industry cannot depend entirely on imports," said Li Jiaxiang, the head of China's civil aviation authority. Between 150 and 170 passenger seats, C919 will be a competitor for Boeing 737 and Airbus 320.

Incorporating a state-of-the-art engine, specialists in the field believe the C919 is comparable as their competitors.

The plane is not fully developed in China, the engine, electronics, wheels, brakes and many other components being manufactured mainly in Europe and the United States. Airplane price is announced to be about 500 million dollars, with about 100 million dollars below the price of the catalog of its competitors.

Price differences may, however, increase in the case of large orders. Chinese media announced that there are already orders for 570 C919 devices from Chinese aviation companies. It is estimated that the global civil aviation market will total $\$ 2$ trillion in the next 20 years. Boeing estimates that just to cope with the domestic market, Chinese airlines will have to acquire over 6,000 passenger planes of different sizes, the cost of which is close to 1 trillion dollars. 


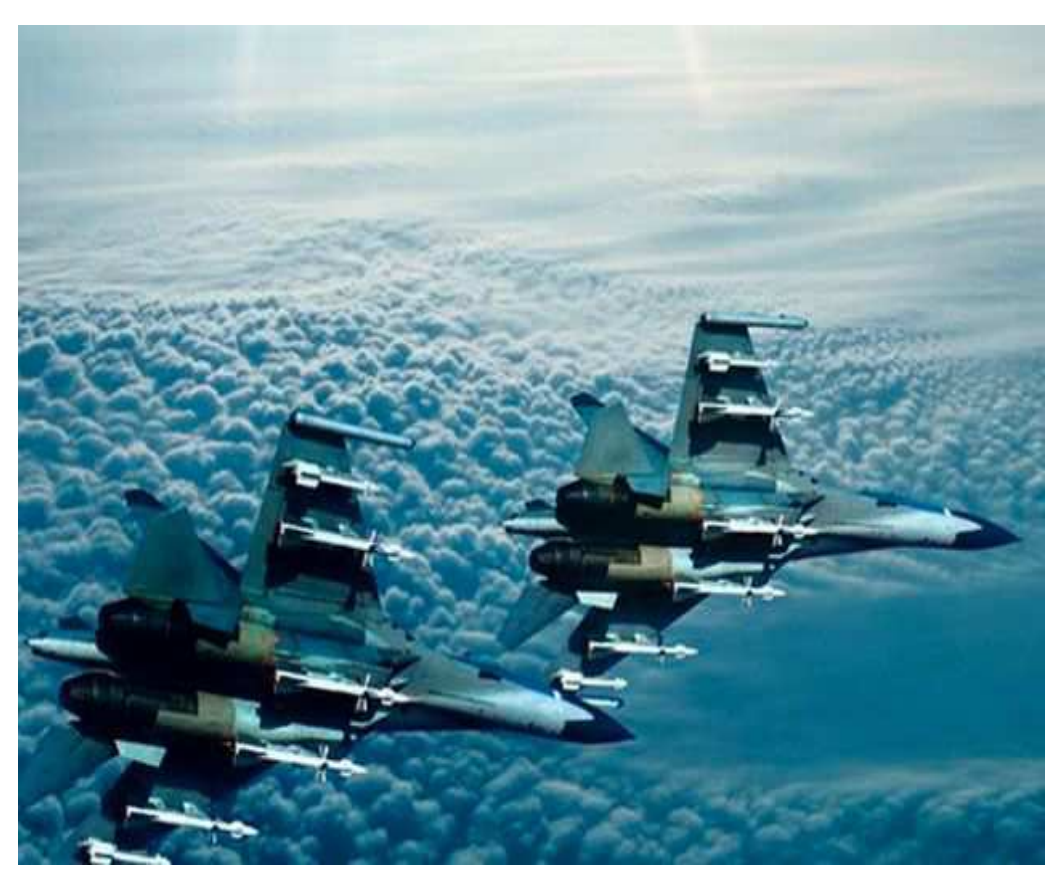

Fig. 1: China has invested heavily in the army in recent years, developing state-of-the-art weapons and building airports in the South China Sea

The next step for the C919 to enter the global market will be the required certificates from American and European agencies, the FAA and EASA, which regulate the commercial aviation sector. Qatar Airways CEO Akbar Al Baker said shortly afterward that "there is no hesitation in a plane made in China, as long as they are built to a certain standard. There is nothing wrong with buying China-made products, but we are using Chinamade iPhone designed by someone else but manufactured in China. I think it will be good if this monopoly (Boeing / Airbus) is broken" he added this.

China has invested heavily in the army in recent years, developing state-of-the-art weapons and building airports in the South China Sea (Fig. 1).

\section{Results}

C919, the passenger plane developed by China within a national project, was successfully launched at the inauguration of its flight (Fig. 2 and 3). After a series of long delays, this is only the first step by which China is trying to penetrate the international aviation market.

C919, developed and produced by Aircraft Corp. or COMAC in brief, was initially scheduled to be prepared in 2012 with its first flight in 2016. Despite these delays, COMAC will be a serious competitor in the future for the leaders of the Boeing and Airbus civil aviation market, given that $\mathrm{C} 919$ will be up to $50 \%$ lower than the models produced by American and European competitors. This first model of the airplane, still under test, was taken off from Shanghai
Pudong Airport, the event being broadcast live by the media in the Chinese state.

The latter declared the success of this project as a reason for national pride, only six other countries in the world have managed to produce a line plane of this size, especially in the context in which just days ago China launched the first the aircraft produced entirely on the domestic market. China's ambition to develop its own civil aviation industry dates back to the 1970 s when Mao Zedong's wife, Jiang Qing, supported the personal development of this sector. "A strong country must have its own passenger plane.

China's commercial aviation industry cannot depend entirely on imports," said Li Jiaxiang, the head of China's civil aviation authority. Between 150 and 170 passenger seats, C919 will be a competitor for Boeing 737 and Airbus 320. Incorporating a state-of-the-art engine, specialists in the field believe the C919 is comparable as their competitors.

The plane is not fully developed in China, the engine, electronics, wheels, brakes and many other components being manufactured mainly in Europe and the United States. Airplane price is announced to be about 500 million dollars, with about 100 million dollars below the price of the catalog of its competitors.

Price differences may, however, increase in the case of large orders. Chinese media announced that there are already orders for 570 C919 devices from Chinese aviation companies. It is estimated that the global civil aviation market will total $\$ 2$ trillion in the next 20 years. 
Boeing estimates that just to cope with the domestic market, Chinese airlines will have to acquire over 6,000 passenger planes of different sizes, the cost of which is close to 1 trillion dollars. The next step for the C919 to enter the global market will be the required certificates from American and European agencies, the FAA and EASA, which regulate the commercial aviation sector.
Qatar Airways CEO Akbar Al Baker said shortly afterward that "there is no hesitation in a plane made in China, as long as they are built to a certain standard. There is nothing wrong with buying China-made products, but we are using China-made iPhone designed by someone else but manufactured in China. I think it will be good if this monopoly (Boeing/Airbus) is broken" he added this.

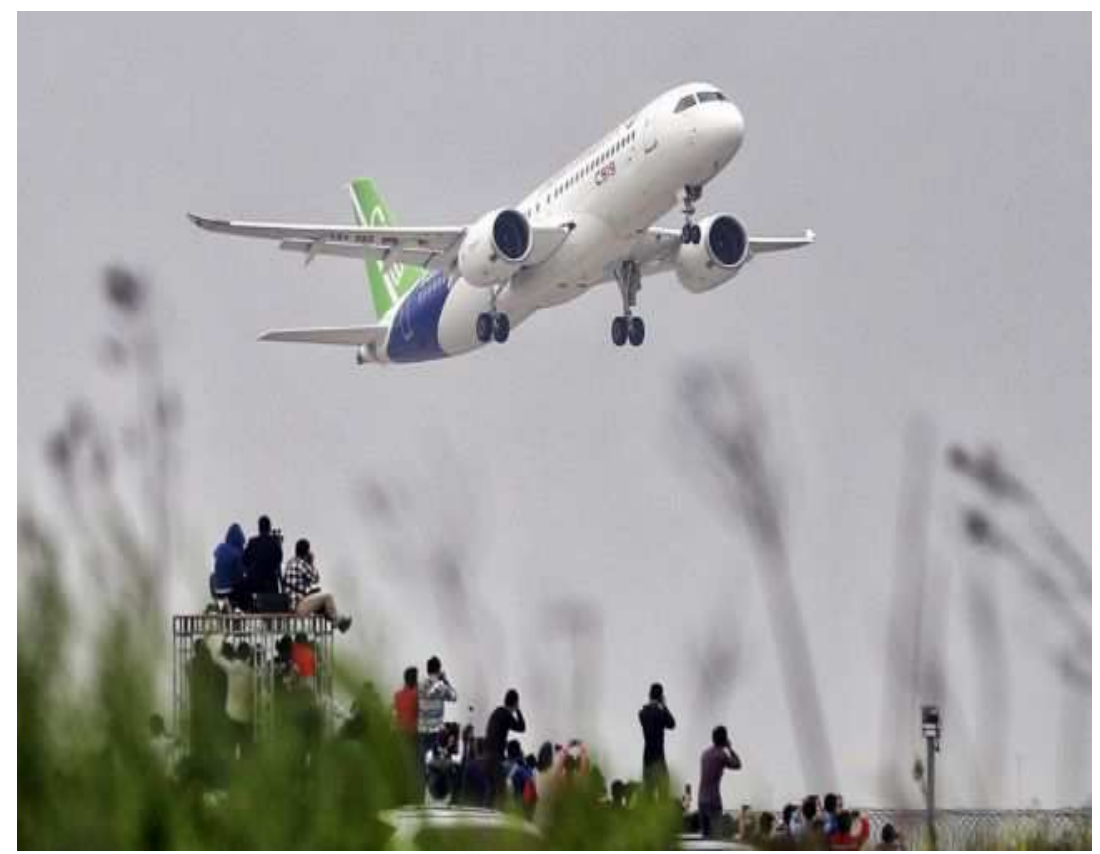

Fig. 2: C919, the passenger plane developed by China within a national project, was successfully launched

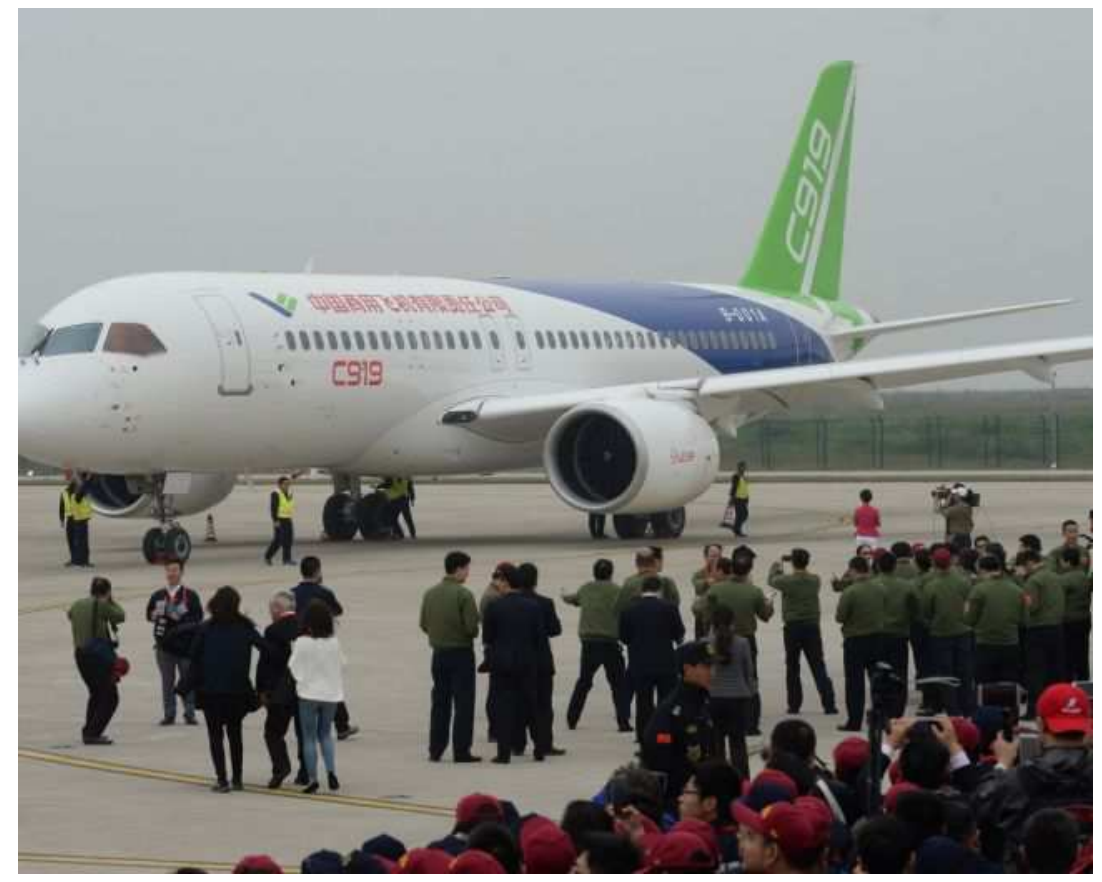

Fig. 3: C919, the passenger plane developed by China within a national project, was successfully launched 


\section{Discussion}

China is a miraculous country that has been developing lately at a galloping pace. China has succeeded in developing and strengthening the electronics and home electronics industries over the past thirty years, then in the past 15 years the car and automotive industry and has now been planning to develop its aerospace and aero industries together with its own passenger planes, so that it no longer needs to appeal to the big companies and especially to the two most famous monopoly today, namely Boeing and Airbus.

Considering China's history, a friendly country with intelligent and working people, the launch of a prototype of its own passenger plane is good news and we want China to be very successful in all its technological enterprises. The plane will evolve with its steps, but it will certainly do so. Given the fact that such an aircraft is a real technological jewel, we can realize that Chinese specialists have evolved a lot over the last 30 years with the country's technological development. Having the courage to produce something like that already says a lot.

\section{Conclusion}

China has invested heavily in the army in recent years, developing state-of-the-art weapons and building airports in the South China Sea.

China is a miraculous country that has been developing lately at a galloping pace. China has succeeded in developing and strengthening the electronics and home electronics industries over the past thirty years, then in the past 15 years the car and automotive industry and has now been planning to develop its aerospace and aero industries together with its own passenger planes, so that it no longer needs to appeal to the big companies and especially to the two most famous monopoly today, namely Boeing and Airbus.

C919, the passenger plane developed by China within a national project, was successfully launched at the inauguration of its flight. After a series of long delays, this is only the first step by which China is trying to penetrate the international aviation market.

C919, developed and produced by Aircraft Corp. or COMAC in brief, was initially scheduled to be prepared in 2012 with its first flight in 2016. Despite these delays, COMAC will be a serious competitor in the future for the leaders of the Boeing and Airbus civil aviation market, given that $\mathrm{C} 919$ will be up to $50 \%$ lower than the models produced by American and European competitors.

This first model of the airplane, still under test, was taken off from Shanghai Pudong Airport, the event being broadcast live by the media in the Chinese state. The latter declared the success of this project as a reason for national pride, only six other countries in the world have managed to produce a line plane of this size, especially in the context in which just days ago
China launched the first the aircraft produced entirely on the domestic market.

China's ambition to develop its own civil aviation industry dates back to the 1970s when Mao Zedong's wife, Jiang Qing, supported the personal development of this sector. "A strong country must have its own passenger plane.

China's commercial aviation industry cannot depend entirely on imports," said Li Jiaxiang, the head of China's civil aviation authority. Between 150 and 170 passenger seats, C919 will be a competitor for Boeing 737 and Airbus 320. Incorporating a state-of-the-art engine, specialists in the field believe the C919 is comparable as their competitors.

\section{Acknowledgement}

The work was appreciated by teams of professors from the departments of automobiles from several universities in Romania and Italy. This text was acknowledged and appreciated by Associate Professor Aniello Riccio SECONDA UNIVERSITA' DEGLI STUDI DI NAPOLI Italy, whom we thanks and in this way.

\section{Funding Information}

Research contract: Contract number 36-5-4D/1986 from 24IV1985, beneficiary CNST RO (Romanian National Center for Science and Technology) Improving dynamic mechanisms internal combustion engines. All these matters are copyrighted. Copyrights: 548-cgiywDssin, from: 22-04-2010, 08:48:48.

\section{Ethics}

Author declares that are not ethical issues that may arise after the publication of this manuscript. This article is original and contains unpublished material.

\section{References}

Ab-Rahman, M.S., H. Guna, MH. Harun, SD. Zan and K. Jumari, 2009. Cost-effective fabrication of self-made $1 \times 12$ polymer optical fiber-based optical splitters for automotive application. Am. J. Eng. Applied Sci., 2: 252-259. DOI: 10.3844/ajeassp.2009.252.259

Abam, F.I., I.U. Ugot and D.I. Igbong, 2012. Performance analysis and components irreversibilities of a $(25$ MW) gas turbine power plant modeled with a spray cooler. Am. J. Eng. Applied Sci., 5: 35-41. DOI: 10.3844/ajeassp.2012.35.41

Abdelkrim, H., S.B. Othman, A.K.B. Salem and S.B. Saoud, 2012. Dynamic partial reconfiguration contribution on system on programmable chip architecture for motor drive implementation. Am. J. Eng. Applied Sci., 5: 15-24.

DOI: 10.3844/ajeassp.2012.15.24 
Abdullah, M.Z., A. Saat and Z. Hamzah, 2011. Optimization of energy dispersive x-ray fluorescence spectrometer to analyze heavy metals in moss samples. Am. J. Eng. Applied Sci., 4: 355-362.

DOI: 10.3844 /ajeassp.2011.355.362

Abdullah, M., A. F.M. Zain, Y. H. Ho and S. Abdullah, 2009. TEC and scintillation study of equatorial ionosphere: A month campaign over sipitang and parit raja stations, Malaysia. Am. J. Eng. Applied Sci., 2: 44-49. DOI: 10.3844/ajeassp.2009.44.49

Abdullah, H. and S.A. Halim, 2009. Electrical and magnetoresistive studies $\mathrm{Nd}$ doped on $\mathrm{La}-\mathrm{Ba}-\mathrm{Mn}-\mathrm{O}_{3}$ manganites for low-field sensor application. Am. J. Eng. Applied Sci., 2: 297-303.

DOI: 10.3844/ajeassp.2009.297.303

Abu-Ein, S., 2009. Numerical and analytical study of exhaust gases flow in porous media with applications to diesel particulate filters. Am. J. Eng. Applied Sci., 2: 70-75.

DOI: 10.3844/ajeassp.2009.70.75

Ahmed, M., R. Khan, M. Billah and S. Farhana, 2010. A novel navigation algorithm for hexagonal hexapod robot. Am. J. Eng. Applied Sci., 3: 320327. DOI: 10.3844/ajeassp.2010.320.327

Akhesmeh, S., N. Pourmahmoud and H. Sedgi, 2008. Numerical study of the temperature separation in the ranque-hilsch vortex tube. Am. J. Eng. Applied Sci., 1: 181-187. DOI: 10.3844 ajeassp.2008.181.187

Al-Abbas, I.K., 2009. Reduced order models of a current source inverter induction motor drive. Am. J. Eng. Applied Sci., 2: 39-43. DOI: 10.3844/ajeassp.2009.39.43

Al Smadi, T.A., 2011. Low cost smart sensor design. Am. J. Eng. Applied Sci., 4: 162-168. DOI: 10.3844/ajeassp.2011.162.168

Aleksic, S. and A. Lovric, 2011. Energy consumption and environmental implications of wired access networks. Am. J. Eng. Applied Sci., 4: 531-539. DOI: 10.3844/ajeassp.2011.531.539

Alhasanat, M.B., A.N. Al Qadi, O.A. Al Khashman and A. Dahamsheh, 2016. Scanning electron microscopic evaluation of self-compacting concrete spalling at elevated temperatures. Am. J. Eng. Applied Sci., 9: 119-127.

DOI: $10.3844 /$ ajeassp.2016.119.127

Ali, K.S. and J.L. Shumaker, 2013. Hardware in the loop simulator for multi-agent unmanned aerial vehicles environment. Am. J. Eng. Applied Sci., 6: 172-177. DOI: 10.3844/ajeassp.2013.172.177

Ali, G.A.M., O. Fouad and S.A. Makhlouf, 2016. Electrical properties of cobalt oxide/silica nanocomposites obtained by sol-gel technique. Am. J. Eng. Applied Sci., 9: 12-16.

DOI: 10.3844 /ajeassp.2016.12.16
Aly, W.M. and M.S. Abuelnasr, 2010. Electronic design automation using object oriented electronics. Am. J. Eng. Applied Sci., 3: 121-127.

DOI: 10.3844/ajeassp.2010.121.127

Anizan, S., K. Yusri, C.S. Leong, N. Amin and S. Zaidi et al., 2011. Effects of the contact resistivity variations of the screen-printed silicon solar cell. Am. J. Eng. Applied Sci., 4: 328-331.

DOI: 10.3844/ajeassp.2011.328.331

Aversa, R., R.V.V. Petrescu, A. Apicella and F.I.T. Petrescu, 2017a. Nano-diamond hybrid materials for structural biomedical application. Am. J. Biochem. Biotechnol., 13: 34-41. DOI: 10.3844 /ajbbsp.2017.34.41

Aversa, R., R.V. Petrescu, B. Akash, R.B. Bucinell and J.M. Corchado et al., 2017b. Kinematics and forces to a new model forging manipulator. Am. J. Applied Sci., 14: 60-80. DOI: 10.3844 /ajassp.2017.60.80

Aversa, R., R.V. Petrescu, A. Apicella, I.T.F. Petrescu and J.K. Calautit et al., 2017c. Something about the $\mathrm{V}$ engines design. Am. J. Applied Sci., 14: 34-52. DOI: 10.3844/ajassp.2017.34.52

Aversa, R., D. Parcesepe, R.V.V. Petrescu, F. Berto and G. Chen et al., 2017d. Process ability of bulk metallic glasses. Am. J. Applied Sci., 14: 294-301. DOI: 10.3844/ajassp.2017.294.301

Aversa, R., R.V.V. Petrescu, B. Akash, R.B. Bucinell and J.M. Corchado et al., 2017e. Something about the balancing of thermal motors. Am. J. Eng. Applied Sci., 10: 200.217. DOI: 10.3844 /ajeassp.2017.200.217

Aversa, R., F.I.T. Petrescu, R.V. Petrescu and A. Apicella, 2016a. Biomimetic FEA bone modeling for customized hybrid biological prostheses development. Am. J. Applied Sci., 13: 1060-1067. DOI: 10.3844/ajassp.2016.1060.1067

Aversa, R., D. Parcesepe, R.V. Petrescu, G. Chen and F.I.T. Petrescu et al., 2016b. Glassy amorphous metal injection molded induced morphological defects. Am. J. Applied Sci., 13: 1476-1482. DOI: 10.3844/ajassp.2016.1476.1482

Aversa, R., R.V. Petrescu, F.I.T. Petrescu and A. Apicella, 2016c. Smart-factory: Optimization and process control of composite centrifuged pipes. Am. J. Applied Sci., 13: 1330-1341. DOI: 10.3844/ajassp.2016.1330.1341

Aversa, R., F. Tamburrino, R.V. Petrescu, F.I.T. Petrescu and M. Artur et al., $2016 \mathrm{~d}$. Biomechanically inspired shape memory effect machines driven by muscle like acting NiTi alloys. Am. J. Applied Sci., 13: 1264-1271. DOI: 10.3844/ajassp.2016.1264.1271 
Aversa, R., E.M. Buzea, R.V. Petrescu, A. Apicella and M. Neacsa et al., 2016e. Present a mechatronic system having able to determine the concentration of carotenoids. Am. J. Eng. Applied Sci., 9: 1106-1111.

DOI: 10.3844 /ajeassp.2016.1106.1111

Aversa, R., R.V. Petrescu, R. Sorrentino, F.I.T. Petrescu and A. Apicella, 2016f. Hybrid ceramopolymeric nanocomposite for biomimetic scaffolds design and preparation. Am. J. Eng. Applied Sci., 9: 1096-1105.

DOI: 10.3844/ajeassp.2016.1096.1105

Aversa, R., V. Perrotta, R.V. Petrescu, C. Misiano and F.I.T. Petrescu et al., 2016g. From structural colors to super-hydrophobicity and achromatic transparent protective coatings: Ion plating plasma assisted $\mathrm{TiO}_{2}$ and $\mathrm{SiO}_{2}$ Nano-film deposition. Am. J. Eng. Applied Sci., 9: 1037-1045.

DOI: 10.3844/ajeassp.2016.1037.1045

Aversa, R., R.V. Petrescu, F.I.T. Petrescu and A. Apicella, 2016h. Biomimetic and evolutionary design driven innovation in sustainable products development, Am. J. Eng. Applied Sci., 9: 1027-1036. DOI: 10.3844/ajeassp.2016.1027.1036

Aversa, R., R.V. Petrescu, A. Apicella and F.I.T. Petrescu, 2016i. Mitochondria are naturally micro robots-a review. Am. J. Eng. Applied Sci., 9: 991-1002.

DOI: 10.3844/ajeassp.2016.991.1002

Aversa, R., R.V. Petrescu, A. Apicella and F.I.T. Petrescu, 2016j. We are addicted to vitamins $C$ and EA review. Am. J. Eng. Applied Sci., 9: 1003-1018. DOI: 10.3844/ajeassp.2016.1003.1018

Aversa, R., R.V. Petrescu, A. Apicella and F.I.T. Petrescu, 2016k. Physiologic human fluids and swelling behavior of hydrophilic biocompatible hybrid ceramo-polymeric materials. Am. J. Eng. Applied Sci., 9: 962-972.

DOI: 10.3844/ajeassp.2016.962.972

Aversa, R., R.V. Petrescu, A. Apicella and F.I.T. Petrescu, 20161. One can slow down the aging through antioxidants. Am. J. Eng. Applied Sci., 9: 1112-1126. DOI: 10.3844/ajeassp.2016.1112.1126

Aversa, R., R.V. Petrescu, A. Apicella and F.I.T. Petrescu, 2016m. About homeopathy or «Similia similibus curentur $\gg$. Am. J. Eng. Applied Sci., 9: 1164-1172. DOI: 10.3844/ajeassp.2016.1164.1172

Aversa, R., R.V. Petrescu, A. Apicella and F.I.T. Petrescu, 2016n. The basic elements of life's. Am. J. Eng. Applied Sci., 9: 1189-1197.

DOI: 10.3844/ajeassp.2016.1189.1197

Aversa, R., F.I.T. Petrescu, R.V. Petrescu and A. Apicella, 2016o. Flexible stem trabecular prostheses. Am. J. Eng. Applied Sci., 9: 1213-1221. DOI: 10.3844/ajeassp.2016.1213.1221
Bakar, R.A., M.K. Mohammed and M.M. Rahman, 2009. Numerical study on the performance characteristics of hydrogen fueled port injection internal combustion engine, Am. J. Eng. Applied Sci., 2: 407-415. DOI: 10.3844 /ajeassp.2009.407.415

Bedon, C. and C. Amadio, 2016. A unified approach for the shear buckling design of structural glass walls with non-ideal restraints. Am. J. Eng. Applied Sci., 9: 64-78. DOI: 10.3844/ajeassp.2016.64.78

Bolonkin, A., 2009a. Femtotechnology: Nuclear matter with fantastic properties. Am. J. Eng. Applied Sci., 2: 501-514. DOI: 10.3844/ajeassp.2009.501.514

Bolonkin, A., 2009b. Converting of matter to nuclear energy by ab-generator. Am. J. Eng. Applied Sci., 2: 683-693. DOI: 10.3844/ajeassp.2009.683.693

Boucetta, A., 2008. Vector control of a variable reluctance machine stator and rotor discs imbricates. Am. J. Eng. Applied Sci., 1: 260-265. DOI: 10.3844/ajeassp.2008.260.265

Cardu, M., P. Oreste and T. Cicala, 2009. Analysis of the tunnel boring machine advancement on the Bologna-Florence railway link. Am. J. Eng. Applied Sci., 2: 416-420.

DOI: 10.3844 /ajeassp.2009.416.420

Chen, G. and L. Xu, 2016. A general strategy to enhance up conversion luminescence in rare-earth-ion-doped oxide nanocrystals. Am. J. Eng. Applied Sci., 9: 7983. DOI: 10.3844 /ajeassp.2016.79.83

Darabi, A., S.A. Soleamani and A. Hassannia, 2008. Fuzzy based digital automatic voltage regulator of a synchronous generator with unbalanced loads. Am. J. Eng. Applied Sci., 1: 280-286. DOI: 10.3844/ajeassp.2008.280.286

Daud, H., N. Yahya, A.A. Aziz and M.F. Jusoh, 2008. Development of wireless electric concept powering electrical appliances. Am. J. Eng. Applied Sci., 1: 12-15. DOI: 10.3844/ajeassp.2008.12.15

Djalel, D., M. Mourad and H. Labar, 2013. New approach of electromagnetic fields of the lightning discharge. Am. J. Eng. Applied Sci., 6: 369-383. DOI: 10.3844/ajeassp.2013.369.383

Ebrahim, N.A., S. Ahmed, S.H.A. Rashid and Z. Taha, 2012. Technology use in the virtual R\&D teams. Am. J. Eng. Applied Sci., 5: 9-14. DOI: 10.3844/ajeassp.2012.9.14

El-Labban, H.F., M. Abdelaziz and E.R.I. Mahmoud, 2013. Modification of carbon steel by laser surface melting: Part I: Effect of laser beam travelling speed on microstructural features and surface hardness. Am. J. Eng. Applied Sci., 6: 352-359. DOI: 10.3844/ajeassp.2013.352.359 
Elliott, A., S. AlSalihi, A.L. Merriman and M.M. Basti, 2016. Infiltration of nanoparticles into porous binder jet printed parts. Am. J. Eng. Applied Sci., 9: 128-133. DOI: 10.3844/ajeassp.2016.128.133

El-Tous, Y., 2008. Pitch angle control of variable speed wind turbine. Am. J. Eng. Applied Sci., 1: 118-120. DOI: 10.3844/ajeassp.2008.118.120

Farahani, A.S., N.M. Adam and M.K.A. Ariffin, 2010. Simulation of airflow and aerodynamic forces acting on a rotating turbine ventilator. Am. J. Eng. Applied Sci., 3: 159-170.

DOI: 10.3844 /ajeassp.2010.159.170

Fathallah, A.Z.M. and R.A. Bakar, 2009. Prediction studies for the performance of a single cylinder high speed spark ignition linier engine with spring mechanism as return cycle. Am. J. Eng. Applied Sci., 2: 713-720. DOI: 10.3844/ajeassp.2009.713.720

Fen, Y.W., W.M.M. Yunus, M.M. Moksin, Z.A. Talib and N.A. Yusof, 2011. Optical properties of crosslinked chitosan thin film with glutaraldehyde using surface Plasmon resonance technique. Am. J. Eng. Applied Sci., 4: 61-65. DOI: 10.3844/ajeassp.2011.61.65

Feraga, C.E., A. Moussaoui, A. Bouldjedri and A. Yousfi, 2009. Robust position controller for a permanent magnet synchronous actuator. Am. J. Eng. Applied Sci., 2: 388-392.

DOI: 10.3844/ajeassp.2009.388.392

Hassan, M., H. Mahjoub and M. Obed, 2012. Voicebased control of a DC servo motor. Am. J. Eng. Applied Sci., 5: 89-92.

DOI: 10.3844 /ajeassp.2012.89.92

Helmy, A.K. and G.S. El-Taweel, 2010. Neural network change detection model for satellite images using textural and spectral characteristics. Am. J. Eng. Applied Sci., 3: 604-610. DOI: 10.3844/ajeassp.2010.604.610

Ho, C.Y.F., B.W.K. Ling, S.G. Blasi, Z.W. Chi and W.C. Siu, 2011. Single step optimal block matched motion estimation with motion vectors having arbitrary pixel precisions. Am. J. Eng. Applied Sci., 4: 448-460. DOI: 10.3844/ajeassp.2011.448.460

Huang, B., S.H. Masood, M. Nikzad, P.R. Venugopal and A. Arivazhagan, 2016. Dynamic mechanical properties of fused deposition modelling processed polyphenylsulfone material. Am. J. Eng. Applied Sci., 9: 1-11.

DOI: 10.3844/ajeassp.2016.1.11

Idarwazeh, S., 2011. Inverse discrete Fourier transform-discrete Fourier transform techniques for generating and receiving spectrally efficient frequency division multiplexing signals. Am. J. Eng. Applied Sci., 4: 598-606.

DOI: $10.3844 /$ ajeassp.2011.598.606
Ismail, M.I.S., Y. Okamoto, A. Okada and Y. Uno, 2011. Experimental investigation on micro-welding of thin stainless steel sheet by fiber laser. Am. J. Eng. Applied Sci., 4: 314-320.

DOI: 10.3844 ajeassp.2011.314.320

Jalil, M.I.A. and J. Sampe, 2013. Experimental investigation of thermoelectric generator modules with different technique of cooling system. Am. J. Eng. Applied Sci., 6: 1-7. DOI: 10.3844 /ajeassp.2013.1.7

Jaoude, A.A. and K. El-Tawil, 2013. Analytic and nonlinear prognostic for vehicle suspension systems. Am. J. Eng. Applied Sci., 6: 42-56. DOI: 10.3844 /ajeassp.2013.42.56

Kaewnai, S. and S. Wongwises, 2011. Improvement of the runner design of francis turbine using computational fluid dynamics. Am. J. Eng. Applied Sci., 4: 540-547. DOI: 10.3844 /ajeassp.2011.540.547

Kamble, V.G. and N. Kumar, 2016. Fabrication and tensile property analysis of polymer matrix composites of graphite and silicon carbide as fillers. Am. J. Eng. Applied Sci., 9: 17-30. DOI: 10.3844/ajeassp.2016.17.30

Kechiche, O.B.H.B., H.B.A. Sethom, H. Sammoud and I.S. Belkhodja, 2011. Optimized highfrequency signal injection based permanent magnet synchronous motor rotor position estimation applied to washing machines. Am. J. Eng. Applied Sci., 4: 390-399. DOI: 10.3844/ajeassp.2011.390.399

Kuli, I., T.M. Abu-Lebdeh, E.H. Fini and S.A. Hamoush, 2016. The use of nano-silica for improving mechanical properties of hardened cement paste. Am. J. Eng. Applied Sci., 9: 146-154. DOI: 10.3844 /ajeassp.2016.146.154

Kunanoppadon, J., 2010. Thermal efficiency of a combined turbocharger set with gasoline engine. Am. J. Eng. Applied Sci., 3: 342-349. DOI: 10.3844/ajeassp.2010.342.349

Kwon, S., Y. Tani, H. Okubo and T. Shimomura, 2010. Fixed-star tracking attitude control of spacecraft using single-gimbal control moment gyros. Am. J. Eng. Applied Sci., 3: 49-55. DOI: 10.3844 ajeassp.2010.49.55

Lamarre, A., E.H. Fini and T.M. Abu-Lebdeh, 2016. Investigating effects of water conditioning on the adhesion properties of crack sealant. Am. J. Eng. Applied Sci., 9: 178-186. DOI: 10.3844/ajeassp.2016.178.186

Lubis, Z., A.N. Abdalla, Mortaza and R. Ghon, 2009. Mathematical modeling of the three phase induction motor couple to DC motor in hybrid electric vehicle. Am. J. Eng. Applied Sci., 2: 708-712. DOI: 10.3844/ajeassp.2009.708.712 
Madani, D.A. and A. Dababneh, 2016. Rapid entire body assessment: A literature review. Am. J. Eng. Applied Sci., 9: 107-118. DOI: 10.3844/ajeassp.2016.107.118

Marghany, M. and M. Hashim, 2009. Robust of doppler centroid for mapping sea surface current by using radar satellite data. Am. J. Eng. Applied Sci., 2: 781-788.

DOI: 10.3844/ajeassp.2009.781.788

Mavukkandy, M.O., S. Chakraborty, T. Abbasi and S.A. Abbasi, 2016. A clean-green synthesis of platinum nanoparticles utilizing a pernicious weed lantana (Lantana Camara). Am. J. Eng. Applied Sci., 9: 84-90.

DOI: 10.3844 /ajeassp.2016.84.90

Moezi, N., D. Dideban and A. Ketabi, 2008. A novel integrated SET based inverter for nano power electronic applications. Am. J. Eng. Applied Sci., 1: 219-222. DOI: 10.3844/ajeassp.2008.219.222

Mohan, K.S.R., P. Jayabalan and A. Rajaraman, 2012. Properties of fly ash based coconut fiber composite. Am. J. Eng. Applied Sci., 5: 29-34.

DOI: 10.3844/ajeassp.2012.29.34

Momani, M.A., T.A. Al Smadi, FM. Al Taweel and K.A. Ghaidan, 2011. GPS ionospheric total electron content and scintillation measurements during the October 2003 magnetic storm. Am. J. Eng. Applied Sci., 4: 301-306.

DOI: $10.3844 /$ ajeassp.2011.301.306

Montgomery, J., T.M. Abu-Lebdeh, S.A. Hamoush and M. Picornell, 2016. Effect of nano-silica on the compressive strength of harden cement paste at different stages of hydration. Am. J. Eng. Applied Sci., 9: 166-177.

DOI: $10.3844 /$ ajeassp.2016.166.177

Nachiengtai, T., W. Chim-Oye, S. Teachavorasinskun and W. Sa-Ngiamvibool, 2008. Identification of shear band using elastic shear wave propagation. Am. J. Eng. Applied Sci., 1: 188-191. DOI: 10.3844 /ajeassp.2008.188.191

Nahas, R. and S.P. Kozaitis, 2014. Metric for the fusion of synthetic and real imagery from multimodal sensors. Am. J. Eng. Applied Sci., 7: 355-362. DOI: 10.3844/ajeassp.2014.355.362

Nandhakumar, S., V. Selladurai and S. Sekar, 2009. Numerical investigation of an industrial robot arm control problem using haar wavelet series. Am. J. Eng. Applied Sci., 2: 584-589.

DOI: 10.3844/ajeassp.2009.584.589

Ng, K.C., M.Z. Yusoff, K. Munisamy, H. Hasini and N.H. Shuaib, 2008. Time-marching method for computations of high-speed compressible flow on structured and unstructured grid. Am. J. Eng. Applied Sci., 1: 89-94.

DOI: 10.3844/ajeassp.2008.89.94
Odeh, S., R. Faqeh, L. Abu Eid and N. Shamasneh, 2009. Vision-based obstacle avoidance of mobile robot using quantized spatial model. Am. J. Eng. Applied Sci., 2: 611-619. DOI: 10.3844 /ajeassp.2009.611.619

Opafunso, Z.O., I.I. Ozigis and I.A. Adetunde, 2009. Pneumatic and hydraulic systems in coal fluidized bed combustor. Am. J. Eng. Applied Sci., 2: 88-95. DOI: 10.3844/ajeassp.2009.88.95

Pannirselvam, N., P.N. Raghunath and K. Suguna, 2008. Neural network for performance of glass fibre reinforced polymer plated RC beams. Am. J. Eng. Applied Sci., 1: 82-88.

DOI: 10.3844 ajeassp.2008.82.88

Pattanasethanon, S., 2010. The solar tracking system by using digital solar position sensor. Am. J. Eng. Applied Sci., 3: 678-682.

DOI: 10.3844 /ajeassp.2010.678.682

Petrescu, R.V. and F.I. Petrescu, 2013a. Lockheed Martin. 1st Edn., BoD-Books on Demand, ISBN-10: 3848230739, pp: 114.

Petrescu, R.V. and F.I. Petrescu, 2013b. Northrop. 1st Edn., CreateSpace, pp: 96.

Petrescu, R.V. and F.I. Petrescu, 2013c. The Aviation History or New Aircraft I Color. 1st Edn., CreateSpace, pp: 292.

Petrescu, F.I. and R.V. Petrescu, 2012. New Aircraft II. 1st Edn., Books On Demand, pp: 138.

Petrescu, F.I. and R.V. Petrescu, 2011. Memories about Flight. 1st Edn., CreateSpace, pp: 652.

Petrescu, F.I.T., 2018. About the nuclear particles' structure and dimensions. Comp. Part. Mech. DOI: $10.1007 / \mathrm{s} 40571-018-0206-7$

Petrescu, F.I.T., 2015a. Geometrical synthesis of the distribution mechanisms. Am. J. Eng. Applied Sci., 8: 63-81. DOI: 10.3844/ajeassp.2015.63.81

Petrescu, F.I.T., 2015b. Machine motion equations at the internal combustion heat engines. Am. J. Eng. Applied Sci., 8: 127-137. DOI: 10.3844/ajeassp.2015.127.137

Petrescu, F.I.T., 2012a. Cold nuclear fusion. Plasma Phys. Fusion Technol., 44: 100-100.

Petrescu, R.V., R. Aversa, A. Apicella, S. Li and G. Chen et al., 2016a. Something about electron dimension. Am. J. Applied Sci., 13: 1272-1276. DOI: 10.3844 /ajassp.2016.1272.1276

Petrescu, F.I.T., A. Apicella, R. Aversa, R.V. Petrescu and J.K. Calautit et al., 2016b. Something about the mechanical moment of inertia. Am. J. Applied Sci., 13: $1085-1090$. DOI: 10.3844 /ajassp.2016.1085.1090

Petrescu, F.I.T., A. Apicella, R.V. Petrescu, S.P. Kozaitis and R.B. Bucinell et al., 2016c. Environmental protection through nuclear energy. Am. J. Applied Sci., 13: 941-946. DOI: 10.3844/ajassp.2016.941.946 
Petrescu, R.V., R. Aversa, B. Akash, F. Berto and A. Apicella et al., 2017a. Forces of a 3R robot. J. Mechatron. Robot., 1: 1-14. DOI: $10.3844 /$ jmrsp.2017.1.14

Petrescu, R.V., R. Aversa, B. Akash, F. Berto and A. Apicella et al., 2017b. Direct geometry and cinematic to the MP-3R systems. J. Mechatron. Robot., 1: 15-23. DOI: 10.3844/jmrsp.2017.15.23

Petrescu, R.V., R. Aversa, B. Akash, F. Berto and A. Apicella et al., 2017c. Dynamic elements at MP3R. J. Mechatron. Robot., 1: 24-37. DOI: $10.3844 / j m r s p .2017 .24 .37$

Petrescu, R.V., R. Aversa, B. Akash, F. Berto and A. Apicella et al., 2017d. Geometry and direct kinematics to MP3R with $4 \times 4$ operators. J. Mechatron. Robot., 1 : 38-46. DOI: 10.3844/jmrsp.2017.38.46

Petrescu, R.V., R. Aversa, A. Apicella, M.M. Mirsayar and S. Kozaitis et al., 2017e. Current stage in the field of mechanisms with gears and rods. J. Mechatron. Robot., 1: 47-57. DOI: $10.3844 /$ jmrsp.2017.47.57

Petrescu, R.V., R. Aversa, A. Apicella, M.M. Mirsayar and S. Kozaitis et al., 2017f. Geometry and inverse kinematic at the MP3R mobile systems. J. Mechatron. Robot., 1: 58-65. DOI: $10.3844 /$ jmrsp.2017.58.65

Petrescu, R.V., R. Aversa, A. Apicella, M.M. Mirsayar and S. Kozaitis et al., 2017g. Synthesis of optimal trajectories with functions control at the level of the kinematic drive couplings. J. Mechatron. Robot., 1: 66-74. DOI: 10.3844/jmrsp.2017.66.74

Petrescu, R.V., R. Aversa, A. Apicella, M.M. Mirsayar and S. Kozaitis et al., 2017h. The inverse kinematics of the plane system 2-3 in a mechatronic MP2R system, by a trigonometric method. J. Mechatron. Robot., 1: 75-87. DOI: 10.3844/jmrsp.2017.75.87

Petrescu, R.V., R. Aversa, A. Apicella, M.M. Mirsayar and S. Kozaitis et al., 2017i. Serial, anthropomorphic, spatial, mechatronic systems can be studied more simply in a plan. J. Mechatron. Robot., 1: 88-97. DOI: 10.3844/jmrsp.2017.88.97

Petrescu, R.V., R. Aversa, A. Apicella, M.M. Mirsayar and S. Kozaitis et al., 2017j. Analysis and synthesis of mechanisms with bars and gears used in robots and manipulators. J. Mechatron. Robot., 1: 98-108. DOI: $10.3844 / j m r s p .2017 .98 .108$

Petrescu, R.V., R. Aversa, A. Apicella, M.M. Mirsayar and S. Kozaitis et al., 2017k. Speeds and accelerations in direct kinematics to the MP3R systems. J. Mechatron. Robot., 1: 109-117. DOI: $10.3844 /$ jmrsp.2017.109.117

Petrescu, R.V., R. Aversa, A. Apicella, M.M. Mirsayar and S. Kozaitis et al., 20171. Geometry and determining the positions of a plan transporter manipulator. J. Mechatron. Robot., 1: 118-126. DOI: $10.3844 /$ jmrsp.2017.118.126
Petrescu, R.V., R. Aversa, A. Apicella and F.I.T. Petrescu, 2018a. Total Static Balancing and Kinetostatics of the 3R Base Cinematic Chain. J. Mechatron. Robot., 2: 113. DOI: $10.3844 /$ jmrsp.2018.1.13

Petrescu, R.V., R. Aversa, A. Apicella and F.I.T. Petrescu, 2018b. Switching from Flat to Spatial Motion to 3R Mechatronic Systems. J. Mechatron. Robot., 2: 14-22. DOI: 10.3844/jmrsp.2018.14.22

Petrescu, R.V., R. Aversa, A. Apicella and F.I.T. Petrescu, 2018c. The dynamics of the planar cinematic balanced chain at the plan module 3R. J. Mechatron. Robot., 2: 23-34. DOI: $10.3844 /$ jmrsp.2018.23.34

Petrescu, R.V., R. Aversa, A. Apicella and F.I.T. Petrescu, 2018d. Dynamic Kinematics of the Plan Balanced Chain at the Planar Module 3R. J. Mechatron. Robot., 2: 35-44. DOI: 10.3844/jmrsp.2018.35.44

Petrescu, F.I.T. and J.K. Calautit, 2016a. About nano fusion and dynamic fusion. Am. J. Applied Sci., 13: 261-266.

Petrescu, F.I.T. and J.K. Calautit, 2016b. About the light dimensions. Am. J. Applied Sci., 13: 321-325.

Petrescu, F.I.T., 2012b. China. 1st Edn., CreateSpace Independent Publisher, ISBN-13: 978-1469973623, pp: 232.

Pourmahmoud, N., 2008. Rarefied gas flow modeling inside rotating circular cylinder. Am. J. Eng. Applied Sci., 1: 62-65. DOI: 10.3844/ajeassp.2008.62.65

Pravettoni, M., C.S.P. Lòpez and R.P. Kenny, 2016. Impact of the edges of a backside diffusive reflector on the external quantum efficiency of luminescent solar concentrators: Experimental and computational approach. Am. J. Eng. Applied Sci., 9: 53-63. DOI: 10.3844/ajeassp.2016.53.63

Qutbodin, K., 2010. Merging autopilot/flight control and navigation-flight management systems. Am. J. Eng. Applied Sci., 3: 629-630.

DOI: 10.3844 /ajeassp.2010.629.630

Rajbhandari, S., Z. Ghassemlooy and M. Angelova, 2011. The performance of a dual header pulse interval modulation in the presence of artificial light interferences in an indoor optical wireless communications channel with wavelet denoising. Am. J. Eng. Applied Sci., 4: 513-519. DOI: 10.3844/ajeassp.2011.513.519

Raptis, K.G., G.A. Papadopoulos, T.N. Costopoulos and A.D. Tsolakis, 2011. Experimental study of load sharing in roller-bearing contact by caustics and photoelasticity. Am. J. Eng. Applied Sci., 4: 294300. DOI: $10.3844 /$ ajeassp.2011.294.300s

Saikia, A. and N. Karak, 2016. Castor oil based epoxy/clay nanocomposite for advanced applications. Am. J. Eng. Applied Sci., 9: 31-40. DOI: 10.3844/ajeassp.2016.31.40 
Semin, A.R. Ismail and R.A. Bakar, 2009a. Combustion temperature effect of diesel engine convert to compressed natural gas engine. Am. J. Eng. Applied Sci., 2: 212-216. DOI: 10.3844/ajeassp.2009.212.216

Semin, A.R. Ismail and R.A. Bakar, 2009b. Effect of diesel engine converted to sequential port injection compressed natural gas engine on the cylinder pressure Vs crank angle in variation engine speeds. Am. J. Eng. Applied Sci., 2: 154-159. DOI: 10.3844/ajeassp.2009.154.159

Semin S., A.R. Ismail and R.A. Bakar, 2009c. Diesel engine convert to port injection $\mathrm{CNG}$ engine using gaseous injector nozzle multi holes geometries improvement: A review. Am. J. Eng. Applied Sci., 2: 268-278. DOI: 10.3844/ajeassp.2009.268.278

Semin and R.A. Bakar, 2008. A technical review of compressed natural gas as an alternative fuel for internal combustion engines. Am. J. Eng. Applied Sci., 1: 302-311.

DOI: 10.3844/ajeassp.2008.302.311

Suarez, L., T.M. Abu-Lebdeh, M. Picornell and S.A. Hamoush, 2016. Investigating the role of fly ash and silica fume in the cement hydration process. Am. J. Eng. Applied Sci., 9: 134-145. DOI: 10.3844/ajeassp.2016.134.145

Taher, S.A., R. Hematti and M. Nemati, 2008. Comparison of different control strategies in GAbased optimized UPFC controller in electric power systems. Am. J. Eng. Applied Sci., 1: 45-52.

DOI: 10.3844 /ajeassp.2008.45.52

Theansuwan, W. and K. Triratanasirichai, 2011. The biodiesel production from roast Thai sausage oil by transesterification reaction. Am. J. Eng. Applied Sci., 4: 130-132.

DOI: 10.3844/ajeassp.2011.130.132

Thongwan, T., A. Kangrang and S. Homwuttiwong, 2011. An estimation of rainfall using fuzzy setgenetic algorithms model. Am. J. Eng. Applied Sci., 4: 77-81. DOI: 10.3844/ajeassp.2011.77.81

Tourab, W., A. Babouri and M. Nemamcha, 2011. Experimental study of electromagnetic environment in the vicinity of high voltage lines. Am. J. Eng. Applied Sci., 4: 209-213. DOI: 10.3844/ajeassp.2011.209.213

Tsolakis, A.D. and K.G. Raptis, 2011. Comparison of maximum gear-tooth operating bending stresses derived from niemann's analytical procedure and the finite element method. Am. J. Eng. Applied Sci., 4: 350-354. DOI: 10.3844/ajeassp.2011.350.354
Waters, C., S. Ajinola and M. Salih, 2016. Dissolution sintering technique to create porous copper with sodium chloride using polyvinyl alcohol solution through powder metallurgy. Am. J. Eng. Applied Sci. 9: 155-165. DOI: 10.3844/ajeassp.2016.155.165

Yeargin, R., R. Ramey and C. Waters, 2016. Porosity analysis in porous brass using dual approaches. Am. J. Eng. Applied Sci., 9: 91-97.

DOI: 10.3844/ajeassp.2016.91.97

Zeferino, R.S., J.A.R. Ramón, E. de Anda Reyes, R.S. González and U. Pal, 2016. Large scale synthesis of $\mathrm{ZnO}$ nanostructures of different morphologies through solvent-free mechanochemical synthesis and their application in photocatalytic dye degradation. Am. J. Eng. Applied Sci., 9: 41-52. DOI: 10.3844/ajeassp.2016.41.52

Zhao, B., 2013. Identification of multi-cracks in the gate rotor shaft based on the wavelet finite element method. Am. J. Eng. Applied Sci., 6: 309-319. DOI: 10.3844/ajeassp.2013.309.319

Zotos, I.S. and T.N. Costopoulos, 2009. On the use of rolling element bearings' models in precision maintenance. Am. J. Eng. Applied Sci., 2: 344-352. DOI: 10.3844/ajeassp.2009.344.352

Zulkifli, R., K. Sopian, S. Abdullah and M.S. Takriff, 2008. Effect of pulsating circular hot air jet frequencies on local and average nusselt number. Am. J. Eng. Applied Sci., 1: 57-61. DOI: 10.3844/ajeassp.2008.57.61

Zulkifli, R., K. Sopian, S. Abdullah and M.S. Takriff, 2009. Experimental study of flow structures of circular pulsating air jet. Am. J. Eng. Applied Sci., 2: 171-175. DOI: 10.3844/ajeassp.2009.171.175

\section{Figure Sources}

Fig. 1: https://storage0.dms.mpinteractiv.ro/media/1/1481/1036 8/14687649/13/clipboard01.jpg

Fig. https://adevarul.ro/assets/adevarul.ro/MRImage/2017/05/ 06/590d02a55ab6550cb8d55399/646x404.jpg

Fig. https://adevarul.ro/assets/adevarul.ro/MRImage/2017/05/ 06/590d040c5ab6550cb8d55b10/646x528.jpg 